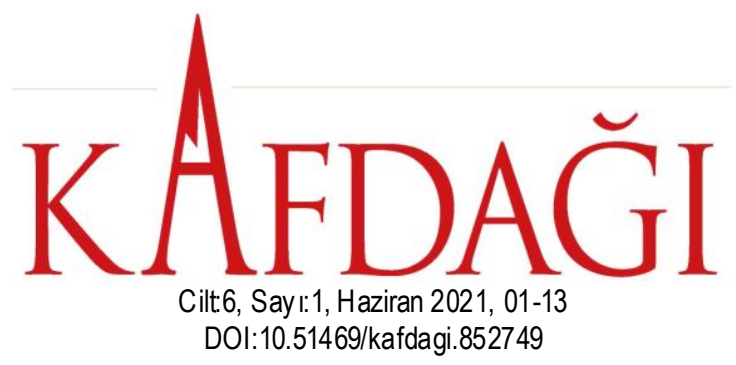

Gönderim Tarihi: 04.01.2021

Kabul Tarihi:29.06.2021

\title{
ú-ri-iš-ḩi ON THE B RONZE HORSE HARNESS DISC OF TABRIZ MUSEUM IN COMPARISON WITH OTHER SIMILAR URARTIAN DISCS INSCRIPTIONS
}

Tebriz Müzesindeki Bronz At Koşum Diski Üzerindeki ú-ri-iš-ḩi Kelimesi ve Diğer Benzer Urartu Disk Yazıtları İle Karşılaştırması Maryam DARA

Assistant Professor of Linguistics, Texts and Inscriptions

Research Center of RICHT

maryam_dara@yahoo.com

ORCID ID: 0000-0003-2190-9638

\begin{abstract}
Urartians left some pieces of evidence of their domination in North West of Iran. Among them are noteworthy metal objects, sometimes with the name of the Urartian king. Some Urartian discs of horse harnesses, sometimes inscribed, are found as well. A similar object exists in Eastern Azarbaijan Museum with the inscription of Argišti I. The name of the king's father is not written, but epigraphically it is attributed to Argišti I. Of course most of the rock inscriptions in the region are the heritage of Argišti II but it was common in Urartian kingdom to move and send objects from one place in a specific era to another one in another Urartian king's ruling epoch. There were some objects as the property of Argišti I in Karmir-Blur and are believed to be Rusa II's. Sarduri II, son of Argišti I, had left a rock inscription in Eastern Azarbaijan and it is therefore possible that he had brought his father's objects to the region. But, as there is no available information regarding its excavation or discovery story one cannot determine its origin.
\end{abstract}

Keywords: Argišti I, Disc, Horse harness, Urartian.

$\ddot{O}_{z}$

Urartular, İran'ın kuzeybatısındaki hakimiyetalanlarında bazı kanıtlar bırakmışlardır. Bunların arasında, bazen Urartu kralının adını taşıyan dikkate değer metal nesnelerde vardır. Bazı Urartu at koșum takımı diskleri de bazen yazılı olarak bulunmuștur. Benzer bir obje Doğu Azerbaycan Müzesi'nde Argišti I'in yazitıyla birlikte bulunmaktadır. Kralın babasının adı yazılı değildir, ancak epigrafik olarak Argišti I'e atfedilmektedir. Bölgedeki kaya yazıtlarının çoğu Argišti II'nin mirasıdır. Ancak Urartu kralliğında belirli bir çağda bir yerden başka bir yere Urartu kralının hükümdarlık dönemindeki nesneleri başka bir yere taşımak ve göndermek yaygındır. Karmir-Blur'da I. Argišti'nin malı olan ve II. Rusa'ya ait olduğuna inanılan bazı nesneler vardır. I. Argišti'nin oğlu II. Sarduri, Doğu Azerbaycan'da bir kaya yazıtı bırakmıştır. Bu nedenle babasının eşyalarını bölgeye getirmiş olabileceği düşünülmektedir. Ancak kazısı ya da keşif öyküsü ile ilgili herhangi bir bilgi bulunmadığından kökeni belirlenememektedir. 
Anahtar Kelimeler: Argišti I, Disk, At Koşum Takımı, Urartu.

\section{Introduction ${ }^{1}$}

Urartians ruled over regions from Armenia, Turkey and Iran for almost three centuries. They expanded their kingdom in the area between the three lakes, Sevan, Van and Urmia and beyond over the course of approximately three centuries from $9^{\text {th }}$ century B.C.E. They were skilled metalworkers and many Urartian extraordinary objects are kept in the museums worldwide.

Urartian inscriptions have been discovered through the years with limited diversity. They wrote the name of the Urartian king or the de ities on many metal and mainly bronze objects. Of course, a fewer number of Urartian objects were inscribed (Belli, 1991, p. 44-46). Roughly 140 cuneiform and hieroglyph inscriptions have been excavated or discovered in Iran.

There were skilled metalworkers among Urartians (Piotrovskij, 2004, p. 237; Melikishvili, 2008, p. 12-15). They had great talent and knowledge of manufacturing metal objects (Ruder and Merhav, 1991, p. 334). Sargon mentioned a long list of metal objects booties in his inscription of his $8^{\text {th }}$ military campaign to Urartian temple of Muṣașir in 714 B.C. (Mayer, 2009, p. 66).

Urartian metal inscriptions included cuneiform, hieroglyph, or both writing systems on the same object. Most of metal objects have been found in Toprak Kale, Karmir-Blur, Chavuştepe nevertheless, a small number of them have inscriptions (Belli, 1991, p. 44). The name of the ruling king and sometimes even the epigraphy of the inscription help us to recognize the era in which the inscriptions have been inscribed. These metal inscriptions were short and mostly consisted of the name of the ruling king or Haldi, the supreme deity (Dinçol and Dinçol, 2003-2004, p. 124). Generally, these inscriptions included phrases in the form of two most favorable clichés: 1. $u$ $r i-i \check{s}-h i / N I G$ or $\breve{S A}$ in addition to the name of the ruling king (sometimes alongside his father's name) 2. Offered by the king to a de ity (mostly Haldi) (Belli, 1991, p. 46).

Some of the Urartian metal objects of Iran have been studied by

\footnotetext{
${ }^{1}$ The author of the paper shows her appreciation for the kind help of Mirjo Salvini and Ingrid Reindell in the research. Furthermore, the author is grateful to Mr. Es mailee, The Director of Museums in Eastern Azarbaijan, Mr. Yazdani, The Director of Eastern Azarbaijan Museum, and Mrs. Sariraee, Curator in Eastern Azarbaijan Museum.
} 
Ghrishman (1964), Barnett and Curtis (1973), Taşyürek (1975), Belli (19767), Frankel (1979), Se idl (1980), Salvini (Salvini 1980, 2012), Gropp (1981), van den Berghe and de Mayer (1982-1983), Merhav (1991), Harutjunjan (2001), Bashashkanzaq (2004), Dalalian and Grekyan (2004), Razmjou (2004), Payne (2006), Sabouri Nojehdehi (2012) and the author (2017, 2019).

A bronze disc was handed over to the Eastern Azarbaijan Museum of Tabriz by a villager from Varzaghan. Therefore, the exact site and time of discovery is not specified. This object is most probably attached to the horse harness and there is a round one-line inscription of Argišti on it. According to the epigraphy this is written in the era of Argišti I. $\dot{u}$-ri-ǐs-hi is the second word in the inscription that shows this is the property of Argišti I. The focus of this paper is to study this bronze disc and to compare it with other similar objects from different Urartian sites.

\section{Urartian Disc of Eas tern Azarbaijan Muse um}

A villager from Varzaghan (Ahar) have handed a disc over to the Archaeology Museum of Eastern Azarbaijan, in Tabriz, in 80s. It was registered with the number 7563 and now is in Urartian section for permanent exhibition. The disc was given to Rasoul Bashashkanzaq for studying, but there is no published paper available. ${ }^{m}$ ar-gi-iš-ti-i $\dot{u}$-ri-iš-hni (Argišti's property) is inscribed on the mentioned disc (Illustration 1).

Possibly, this is a disc which was attached to the horse harness. Some scholars have called the same objects as votive plaques. Nevertheless, Urartian plaques were flat and quadrilateral and mostly used as offerings with ritual scenes. They were sometimes made in flat human shape as well (Kellner, 1991, p. 286-299).

Urartians used to decorate their chariots and horses and discs were used in the ir decorations. The discs sometimes had a hole in the center or in the sides to be sewed and attached to leather or similar surface. Sometimes they had Urartian motifs or inscriptions to be considered as a royal object. Urartian discs have been found from Išpuini's era to the end of Urartian domination. A similar dis is in Ebnöther collection (Illustration 2) with Išpuini's inscription and a hieroglyph sign of a lion head (Seidl, 1991, p. 83). According to Seidl, discs may have been attached to the leather of harness and was fixed on horses' cheek (Ibid, p. 79). These discs - flat or raised in the center- have been discovered in many places in Ancient Near East. According to Moorey (1971, p. 246), they were attached to belts, horse harnesses, chariots, furniture or shields. However, they were mostly found individually and that is the reason their function is ambiguous.

A decorated disc was found in Hasanlu (Muscarella, 2008, p. 111). 
Azarpay (1968, p. 14) mentioned a disc with Argišti's inscription from Karmir-Blur. These decorative discs were used on clothing and weapon as well as horse harness in Phrygia and north of Iran.

The bronze disc of Tabriz Museum was manufactured by molding techniques. It has the diameter of $90 \mathrm{~mm}$ and an $8 \mathrm{~mm}$ hole in the center. The most raised part is $10 \mathrm{~mm}$ and its weight is $67.1 \mathrm{gr}$. An inscription is engraved around the central hole. The craftsman has made an engraved narrow line in $2 \mathrm{~mm}$ from the sides.

It is shiny and more yellow than normal bronze objects which is the reason of it is firmly being cleaned and rubbed by the discoverer prior to its delivery to the museum. The shiny covering layer is faded away and is just visible on the pores. The color was similar to brass, but less yellow (according to Ingrid Reindell in 2014). The rear is less damaged, but there is a dark trace around the central hole and near the sides. This can be the reason for its attachment to another surface for a long time.

\section{3. u-ri-iš-hi}

Short inscriptions on the objects expressed the kings or a deity's property- unlike long and royal ones about the king's military campaigns, triumphs and constructions (Dinçol and Dinçol, 2003-2004, p. 124). Wilhe $\operatorname{lm}(2002$, p. 125) has translated $u$-ri-ǐs-hni as "weapon" or "piece of equipment" and has divided the word in to two parts as uri=šhe. Therefore, it is a root uri added to suffix šhe (similar to Hurrian ša). Salvini (2012, p. 28, B5-1), Belli (1991, p. 46) and Zimansky (1995, s. 109) suggestd "property" and the author totally agrees with the same translation. Of course the ending $i$ is the suffix for genitive singular in Urartian (Wilhelm, 2002, p. 127). Additionally, Salvini have proposed "offering" and "treasury" according to different texts. Zimansky (1995, p. 109) says that $u$-ri-iš-hi is translated as "warehouse" as well, but "property" is more suitable as it is sometimes replaced by NIG. Although, the shape of the disc shows that it was attached to another object, $\dot{u}$-ri-ǐs-hi is written in many different objects and ${ }^{E} \dot{u}$-ri-iš-hi can be "property warehouse". Therefore, "property" can be more probable. Ghrishman (1964, p. 55) and Bashashkanzagh have cautiously proposed "property of Argišti('s tomb)" or "armory of Argišti" according to Karmir-Blur objects. According to all the mentioned translations, the author preferred "Argišti's property".

$\dot{u}$-ri-ǐs-hi has been only mentioned twice in the Urartian rock inscriptions. "Išpuini, son of Sarduri, sent magnificent army/offering, magnificent herd ..." said Išpuini and Minnua on Kalshin stela (Salvini, 
2008, A 3-11 Ro, § 7-9). ${ }^{2}$ Salvini has translated $\dot{u}$-ri-iš-hi as "army/offering" here as the property can be offered as army or other shapes. Another example of the rock inscription is by the same kings on constructing a temple or similar building. $\dot{u}$-ri-iš-hi in mentioned in line 14 and Salvini (Ibid, p. 3/99) has translated it as "property/weapon". But the previous word of the inscription is damaged and it is difficult to recognize the exact translation.

There are some objects found from Minua's era with similar inscriptions: a bronze abject from Karmir-Blur (Piotrovskij 1955: 43) in Yerevan Historical Museum (Salvini, 2012, p. 28, B 5-1), ${ }^{3}$ a bronze object from near Van Kalasi (Belli, 1993, p. 363; Salvini, 2012, p. 28, B 5-2), ${ }^{4}$ horse fittings from northern shores of Caspian Sea (Ghrishman, 1964, p. 219-220; Salvini, 2012, p. 28, B 5-2), ${ }^{5}$ a bronze helmet from Burmagečit in Elaziğ Museum (Belli, 1993; Salvini, 2012, p. 31, B 5-8). ${ }^{6}$

Some similar inscriptions on objects manufactured in Argišti I's era are as following: a bronze shield from Karmir-Blur (Piotrovskij, 1952, fig. 33.1; Salvini, 2012, p. 36, B 8-9), ${ }^{7}$ a bronze helmet in Ossezia of Georgia (Seidl, 2004, p. 30, Taf. 7b; Salvini, 2012, p. 37, B 8-13), a quiver from Karmir-Blur (Salvini, 2012, p. 37, B 8-16), ${ }^{8}$ a bronze bell from Araxes shore in Nakhchivan (Piotrovskij, 1952, p. 6, fig. 3; Salvini, 2012, p. 40, B 8-22), two bronze objects from Karmir-Blur (Seidl, 2004, p. 33; Salvini, 2012, p. 40, B 8-23A-B), a bronze disc from Karmir-Blur (Seidl, 2004, p. 32; Salvini, 2012 , p. 40, B 8-24), horse harnesses from Karmir-Blur ${ }^{9}$ (Ibid, p. 41, B 8$25 \mathrm{~A}-\mathrm{X}$ ) which are sometimes in bronze with convex center, two objects from an area close to Van Kalasi (Ibid, p. 41, B 8-26-27), ${ }^{10}$ a bronze figurine (Seidl, 2004, p. 33 (E.36), Taf. 17b; Salvini, 2012, p. 41, B 27A).

Additionally, there are some objects with similar inscription manufactured during Sarduri II's kingdom including two bronze shields (Piotrovskij, 1952, p. 62; Salvini, 2012, p. 47, B 9-6) and some bronze vessels (Piotrofskij, 1952, p. 56; Salvini, 2012, p. 51, B 9-20a-21) from Karmir-Blur.

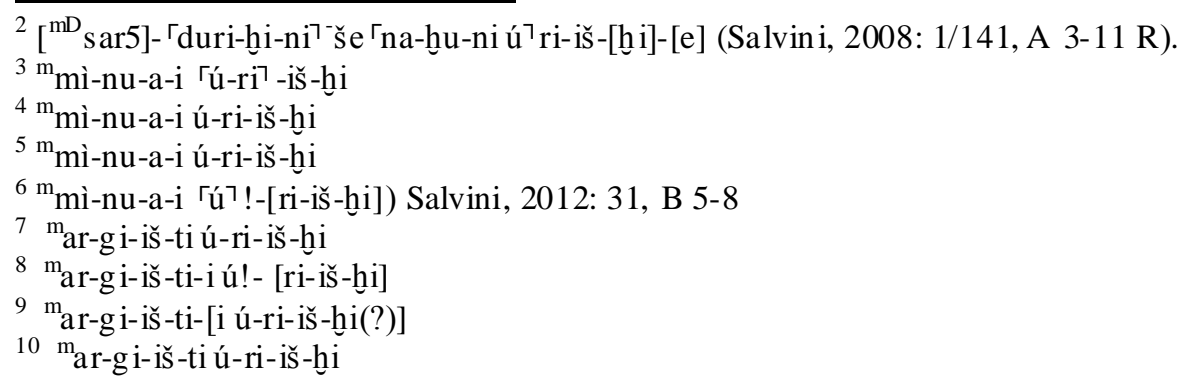


There is a helmet with the inscription of Rusa II, son of Argišti, from Ayanis (Seidl, 2004, p.41) with a little difference in the inscription: "To Haldi, the lord, Rusa, son of Argišti, offered. Hal[di ......], property, to Išpuini” (Salvini, 2012, p. 61, B 12-9). ${ }^{1}$

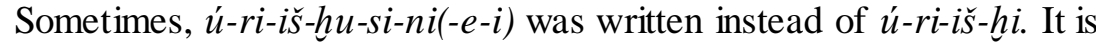
written on a vessel from Minua's era (Seidl, 2004, p. 24, C.1-4 and 7-10) which is translated as "treasury" by Salvini (Ibid, p. 29, B 5-5 A-C). ${ }^{12}$ Argišti I' bronze shield from Karmir-Blur (Ibid, p. 29, B 8-1-2), ${ }^{13}$ a bronze bowl (Ibid, p. 38, B 8-20), ${ }^{14}$ Sarduri II's bronze harness from Upper Anzaf (Ibid, p. 54, B 9-30-31), ${ }^{15}$ Rusa II's bronze candelabra from Toprak-Kale (Ibid, p. 67, B 12-18) ${ }^{16}$ are among the examples.

${ }^{E} \dot{u}$-ri-iš- $h u$ has been written on a bronze bowl in Karmir-Blur from Sarduri II's era. Salvini (51, B 9-20) translated it as "treasury" or "heritage". ${ }^{17}{ }^{E} u$-ri-iš-hu-si(-e) is written on a bronze bowel from the same site but with Rusa I's inscription (Ibid: 57, B 10-2, 10-3A-C). ${ }^{18}{ }^{\dot{E}} \dot{u}-r i-i s ̌-h u-$ $s i-n i$ is used on a lock of Karmir-Blur from Rusa II's era as well and Salvini (Ibid, p. 65, B-12-15) translated it is "armory". ${ }^{19} \dot{u}$-ri-iš-hil-si-ni was used on a bronze object in Upper Anzaf (Ibid, p. 54, B 9-31). ${ }^{20}$

Therefore, ú-ri-iš-hi and its derivations have been used on the different inscriptions of Urartian rulers. This was used from the moment Urartians used Urartian language and cuneiform on the ir objects. Of course it was used mostly on the metal objects.

The epigraphy of the disc of Eastern Azarbaijan Museum demonstrates that this disc has been attributed to Argišti I. The cuneiform used on it was engraved as short wedges and not long and tailed one. As mentioned earlier, this epigraphy had been favorable from Minua's era ( $c a$. 810 - 785-780 B.C) who was Argišti I's father. It was used until the ruling time of Argišti II's father, Rusa (ca. 730-713 B.C). The wedges became

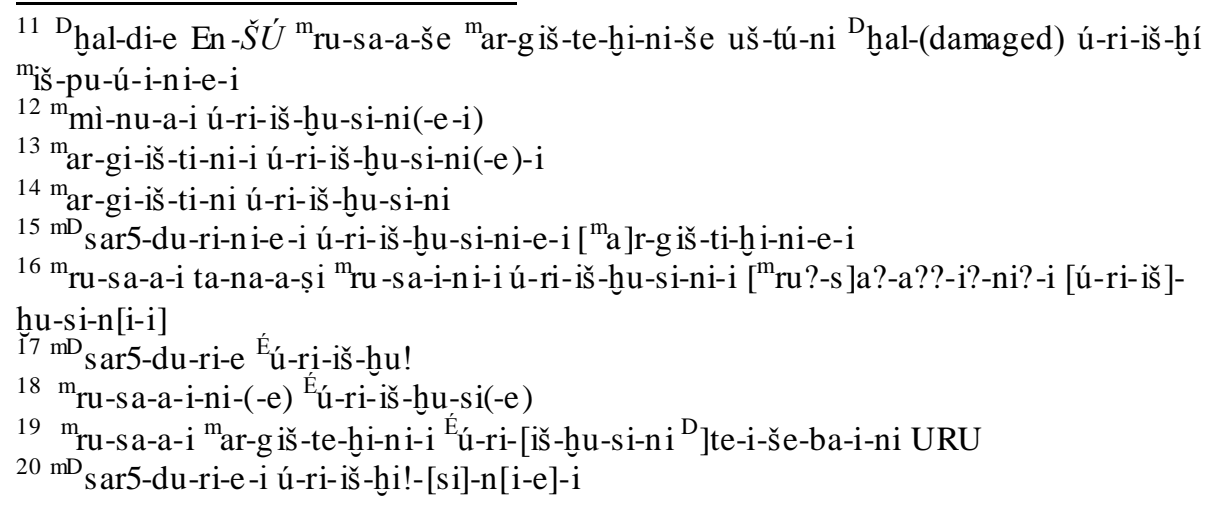


tailed and long again after this era till the end of Urartian domination (Ibid, p. 321-322). Therefore, it cannot be attributed to Argišti II.

One might think that this disc was written in Argišti II's kingdom as Razliq inscription (Dara, 2017, s. 107-110), Nashteban inscription (Ibid, p. 111-116) and Shishe inscription (Ibid, p. 117-122) in Eastern Azarbaijan were Argišti II's heritage. But, Sarduri II, s on of Argišti I, have engraved an inscription in Seqindel as well. It is therefore possible that this disc was transferred to Eastern Azarbaijan at this time as part of an ancient tradition. Some objects from Karmir-Blur were thought to be inscribed in Rusa II's era and manufactured in there but, they were built in Argišti I's era ( $c a$. 780/785-756 B.C) and were moved from Erebuni. Therefore, it was possible that objects from different kings were sent and transformed to other site after their ruling time as part of an ancient tradition (Idem, 1991, p. 11).

\section{Conclusion}

The bronze disc of Eastern Azarbaijan was handed over to the museum in 80 s but unfortunately the information of the villager and the exact time and site of the discovery has not been registered. There are many similar objects found in Urartian sites and the scholars believe they are horse harness discs.

It is shiny, yellow and roughly being rubbed by the discoverer. The shiny covering is removed and only visible on the pores. It is convex and has a one-line inscription around the central hole: ${ }^{m}$ ar-gi-iš-ti-i $u$-ri-iš-h $h i$ (Argišti's property). Scholars have proposed other translations for $\dot{u}$-ri-iš-hi as "weapon", "piece of equipment", "offering", "treasury", "warehouse", "army" and "armory" but, the author prefers and agrees with "property".

$\dot{u}$-ri-iš-hi has been observed twice on stone inscriptions of co-reign of Išpuini and Minua. But many objects, mostly in bronze, have the same word from Minua, Argišti I, Sarduri II, Rusa I and Rusa II's era. But these objects have not been manufactured in all the kings' era. $u$-ri-iš-h $i$ had been written since the Urartian language and cuneiform was being used in co-reign of Išpuini and Minua.

Objects with similar inscriptions have been discovered from KarmirBlur, Van, Ossezia, Nakhchivan, Burmagečit, Upper Anzaf and ToprakKale. These objects are mainly weapon, horse fitting, lock, vessels and similar discs. But $\dot{u}-r i-i \check{s}-h i$ has not been observed on the ceramics, clay tablets, seals and seals impressions.

There are some derivations from $\dot{u}-r i-i \check{s}-h i$ on the objects as $\dot{u}-r i-i s ̌-h i !-$ si-ni, $\dot{u}$-ri-iš-hu-si-ni(-e-i) $\dot{u}-r i-i \grave{s}-h u-s i-n i(-e-i),{ }^{\dot{E}} \dot{u}-r i-i \grave{s}-h u !,{ }^{\dot{E}} \dot{u}-r i-i s ̌-h u-s i(-$ e), ${ }^{\dot{E}} \dot{u}-r i-i \grave{s}-h u-s i-n i$.

The author suggests that this disc is the property of Argišti I as the 
epigraphy is more similar to short triangles not tailed and extended ones. This epigraphy has been used during the era of Minua, father of Argišti I, to Rusa, father of of Argišti II and not of Argišti II. Of course most of the rock inscriptions in the region are the heritage of Argišti II but it was common in Urartian king dom to move and send objects from one place in a specific era to another one in another Urartian king's ruling epoch. There were some objects as the property of Argišti I in Karmir-Blur and are believed to be Rusa II's. Sarduri II, son of Argišti I, had left a rock inscription in Eastern Azarbaijan and it is therefore possible that he had brought his father's objects to the region. But, as there is no available information regarding its excavation or discovery story one cannot determine its origin.

\section{REFERENCES}

Azarpay, G. (1968), Urartian art and artifacts, Berkeley and Los Angeles: University of California Press.

Barnett, R. D.; Curtis, J. E. (1973). A review of acquisitions 1963-70 of western Asiatic antiquities, British Museum Quarterly XXXVII, 133.

Bashashkanzaq, R. (2004). Bracelet inscription of Tul-e Gilan, Archaeological excavations in ancient sites of Tul-e Gilan Talesh (Kavoshhaye bastanshenasi dar mohavatehaye bastaniye Tul-e Gilan-Talesh, RICHT, Gilan, 83-90.

Belli. O. (1976-7). Van bölge mü zes indeki çivi yazili Urartu tunç eserleri, Anadolu Arastirmalari, 177-225.

Belli. O. (1983), Van'da (Tušpa) bulunan Urartu krallarina ait çiviyazil izirhgö güslükleri, $A n A r$.

Belli. O. (1991), Inscribed metal objects, R. Merhav (ed.), Urartu: a metalworking center in the first millennium B.C.E, (The Israel Museum, Jerusalem), May 28 - October 1991, Jerusalem: 43-49.

Belli. O. (1993), Der beschriftet Bronzehelm des Königs Menuaaus der Festung Burmag eçitbei Tunceli, M.J. Mellink and E. Porada and T. Özgüc (Eds.), Aspects of Art and Iconography: Anatolia and its Neighbors. Studies in Honor of Nimet Özgüç, Ankara: 61-67.

van den Berghe, L.; de Mayer, L. (1982-1983). Urartu een vergeten cultuur uit het bergland Armenie, Centru m voor kunst en cultuur, Saint Petersburg.

Dalalian, T.; Grekian, Y. (2004). An Urartian bracelet from Gilan, I ran and The Caucasus, vol. 8.1, Brill, Leiden-Boston, 1-6.

Dara, M. (2017). Dara, Urartain cuneiform inscriptions from Iran, RICHT, Tehran.

Dara, M. (2019). New Observations Regarding the Urartian Inscription of the Tul-e Talesh Bracelet, P. S. Avetisyan- R. Dan- Y. J. Grekyan (eds.), Over the mountains and far away, Archeopress, Oxford, 187-190.

Dinçol, A. M.; Dinçol, B. (2003-2004), Metal artifacts and weapons with cuneiform inscriptions, Urartu: Savas ve estetik (Urartu: War and Aesthetics), Istanbul: Yapi Kredi Cultural Activities: 119-128. 
Frankel, D. (1979). The ancient kingdom of Urartu, London.

Ghrishman, R. (1964), Deuxoeilléres en bronze des rois d'Urartu, Artibus Asiae 27: 49-60.

Ghrishman. R. (1964). Deux oeilléres en bronze des rois d'Urartu, Artibus Asiae 27, 49-60.

Gropp, G. (1981). Ein Pferdegeschirr und Streitwagen aus Urartu, IA XVI, 95-123.

Harutjunjan, N. V. (2001). Korpus Urartskich Klinoobraznych Nadpisej, Nacional'naja Akademija Nauk Respubliki Armenii, Institut Vostokovedenija (Izdatel'stvo "GITUTJUN"), Yerevan.

Kellner, H- J. (1991), Votive plaques, R. Merhav (ed.), Urartu: a metalworking center in the first millennium B.C.E, (The Israel Museum, Jerusalem), May 28 - October 1991, Jerusalem: 285-299.

Mayer, W. (2009), Gozareshe lashkarkeshye Sargon be urartu dar sale 714 (Sargons Feldzug gegen Urartu 714 v.chr: Text und Übersetzung), F. Najd Samiee (trans.), Western Azarbaijan: Sazmane Mirase Farhangi, Sanaye'e Dasti va Gardeshgari-Ganjineye Honar.

Melikišvili, G. A. (2008), Zabane Urartui, Tehran: Moaseseye Farhangi va Entesharatie Pazineh.

Merhav, R. (1991). Everyday and ceremonial utensils, R. Merhav (ed.), Urartu, a metalworking center in the first millennium B.C.E., (The Israel Museum, Jerusalem), May 28 - October 1991, Jerusalem, 200-243.

Moorey, P. R. S. (1971), Catalogue of the ancient Persian bronzes in the Ashmolean Museum, Oxford.

Muscarella, O. W. (2008), Boronz va ahanhaye Hasanlu (Bronzes and Irons of Hasanlu), A. Sadraee and S. Alyun (trans), Western Azarbaijan: Sazmane Mirase Farhangi, Sanaye'e Dasti va Gardeshgari Azarbaijane Gharbi and Ganjineye Honar.

Payne, M. (2006). Urartu Çiviyazili Belgeler Kataloğu, Istanbul, Arkeloji ve sanat yayinlari.

Piotrovskij, B. B. (1952), Rezul'tatyraskopok 1949-1950 gg., Erevan.

Piotrovskij, B. B. (1955), Karmir-blur III. Rezul'tatyraskopok 1951-1953 gg., Erevan.

Piotrovskij, B. B. (2004). Urartian civilization, Hamid Khatib Shahidi (trans), Tehran, Sazmane Mirase Farhangie Keshvar-Pazhuheshkadeye Bastanshenasi.

Razmjou, Sh. (2004). A bronze bracelet with the Urartian inscription from Tul-e Gilan (Yek dastband-e mefraghin ba neveshteye urartuee az tul-e gilan), Archaeological excavations in ancient sites of Tul-e Gilan Talesh (Kavoshhaye bastanshenasi dar mohavatehaye bastani-e tul-e gilan-e talesh), RICHT, Gilan, 92-97.

Ruder, A.; Merhav, R. (1991), Technologies of production of metal artifacts in the Urartu culture, R. Merhav (ed.), Urartu: a metalworking center in the first millennium B.C.E, (The Israel Museum, Jerusalem), May 28 - October 1991, Jerusalem: 333-353. 
Sabouri Nojehdehi, R. (2012). Urartian helmets in Reza Abbasi Museum, Iran, A. Çilingiroğlu and A. Sagona (eds.), Anatolian Iron Ages 7 (The proceedings of the seventh Anatolian Iron Ages Colloquium held at Edirne 19-24 April 2010), Peeters, Leuven-Paris-Walpole, 211-219.

Salvini, M. (1980). Iscrizioni cuneiformi urartee su oggetti di metallo, ISMEA 22, 181-190.

Salvini, M. (2008). Corpus dei Testi Urartei, vol. I and III, Ro ma: CNR.

Salvini, M. (2012). Corpus dei Testi Urartei, vol. IV, Ro ma: CNR.

Seidl, U. (1980). Einige urartäische Bron zezy linder (Deichselkappen?), AMI 13, 6382.

Seidl, U. (1991). Chariot and horse fittings: Horse trappings, R. Merhav (ed.), Urartu: a metalworking center in the first millennium B.C.E, (The Israel Museum, Jerusalem), May 28 - October 1991, Jerusalem: 77-96.

Seidl, U. (2004). Bronze kunst Urartus, Mains.

Taşyurek, O. A. (1975). Some inscribed Urartian bronze armour, Iraq 37, Issue 2, 151-155.

Wilhelm, G. (2002). Urartian, The Cambridge encyclopedia of the World's ancient languages, Cambridge: 119-137.

Zimansky, P. (1995). Urartian material cultures as state assemblage: An anomaly in the archaeology of empire, Bulletin of the American School of Oriental Research 299/300, The archaeology of Empire in Ancient Anatolia, AugNov, A merican School of Oriental Research: 103-115. 


\section{Illustrations}
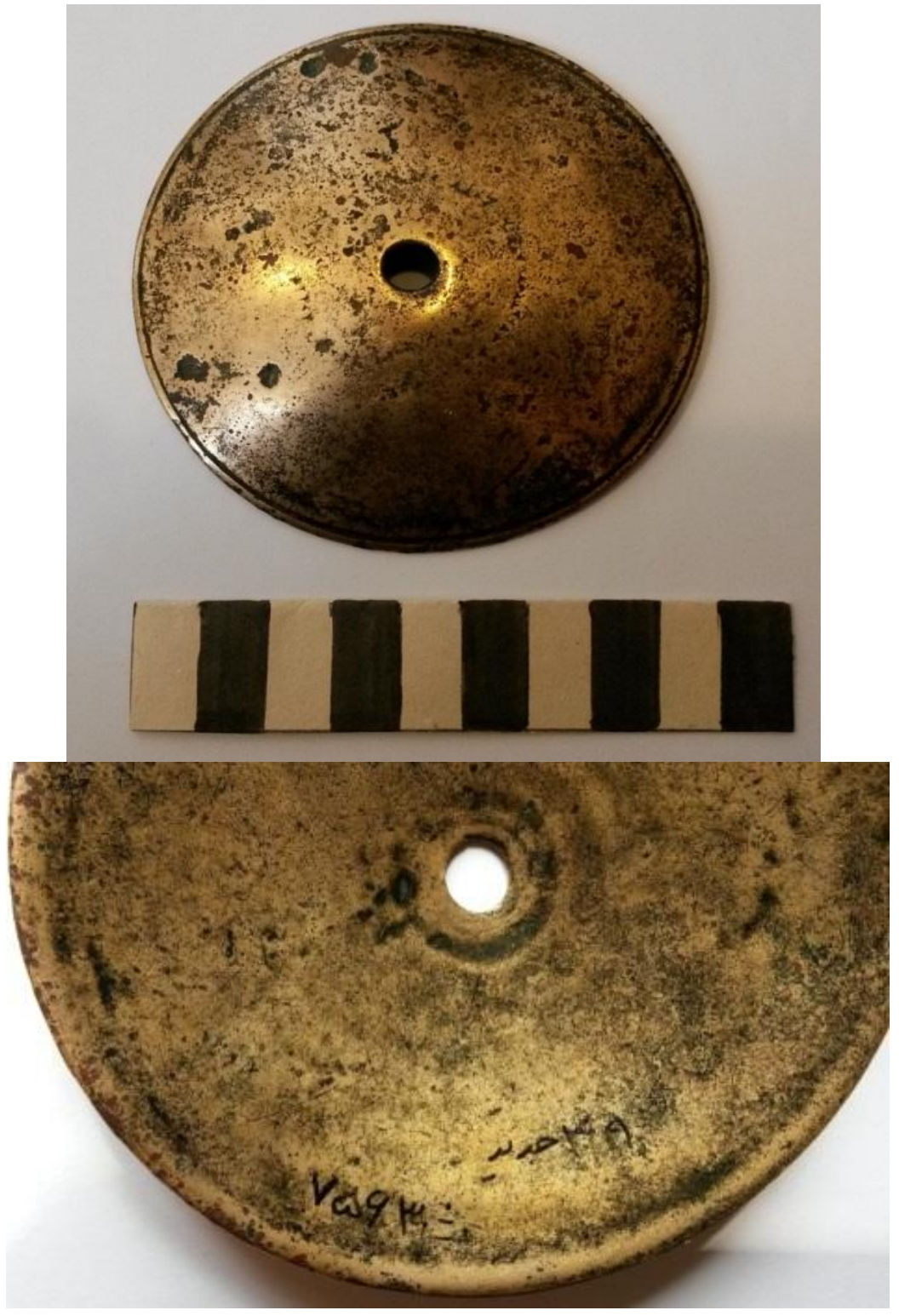

Urartian discs inscriptions

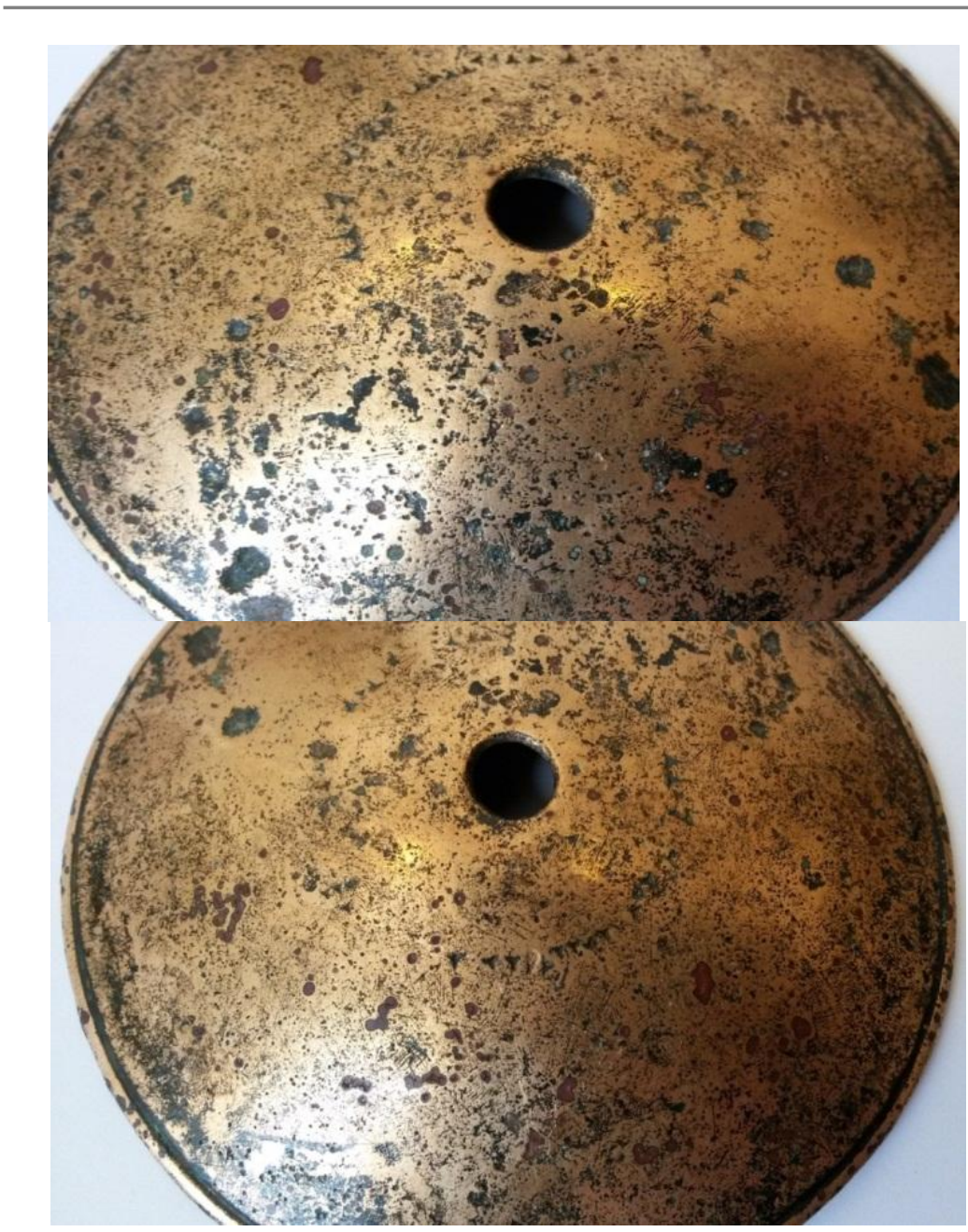

1. The bronze disc with Urartian inscription in Tabriz Museum 


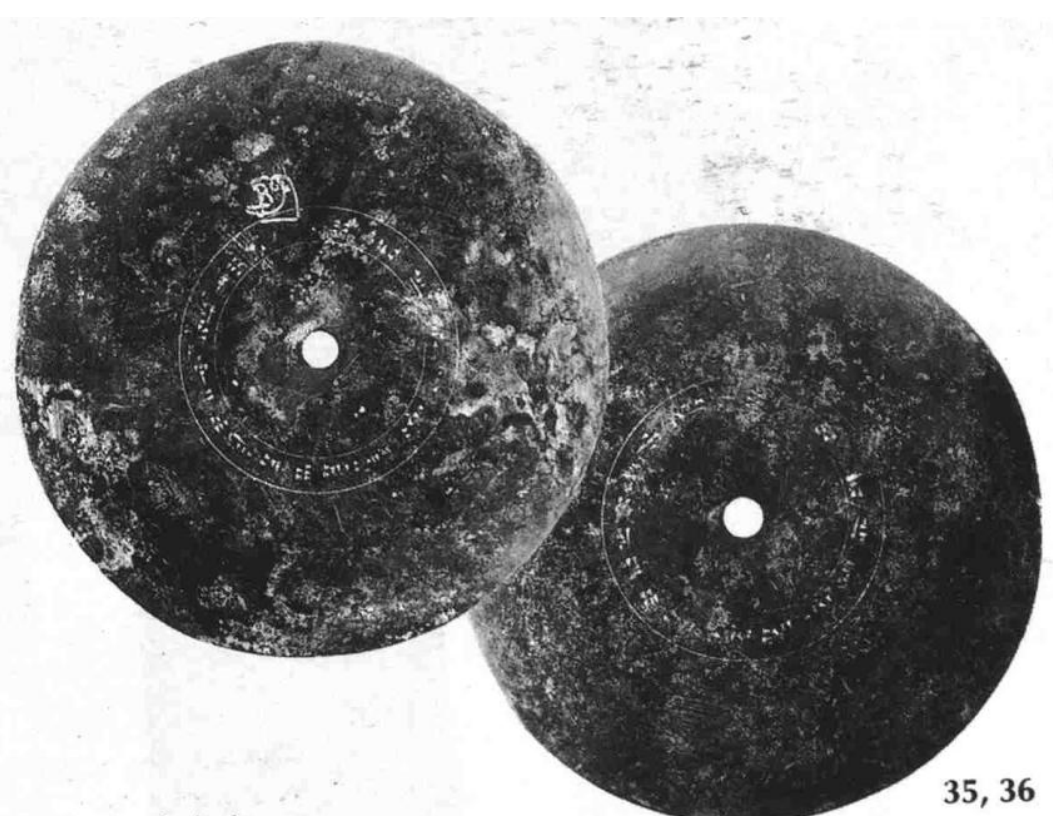

2. Horse harness disc with Išpuini's and hieroglyph inscription (Seidl, 1991: 83) 